\title{
Prevalence of Metabolic Syndrome and Its Components in the Iranian Adult Population: A Systematic Review and Meta-Analysis
}

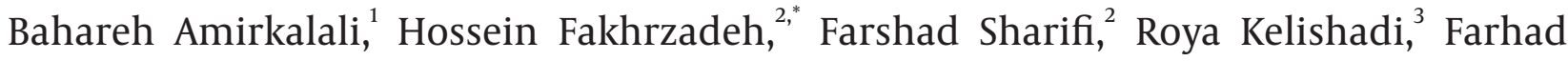 \\ Zamani, ${ }^{1}$ Hamid Asayesh, ${ }^{4}$ Saeid Safiri, ${ }^{5}$ Tahereh Samavat, ${ }^{2}$ and Mostafa Qorbani ${ }^{6,7,8,}$ \\ ${ }^{1}$ Gastrointestinal and Liver disease research Center (GILDRC), Iran University of Medical Sciences, Tehran, IR Iran \\ ${ }^{2}$ Elderly Health Research Center, Endocrinology and Metabolism Population Sciences Institute, Tehran University of Medical Sciences, Tehran, IR Iran \\ ${ }^{3}$ Child Growths and Development Research Center, Isfahan University of Medical Sciences, Isfahan, IR Iran \\ ${ }_{5}^{4}$ Department of Medical Emergencies, Qom University of Medical Sciences, Qom, IR Iran \\ 5 Department of Medical Emergencies, Qom University of Medical Sciences, Qom, IR Iran \\ 6 Department of Public Health, School of Nursing and Midwifery, Maragheh University of Medical Sciences, Maragh \\ ${ }_{7}^{7}$ Non-communicable Diseases Research Center, Endocrinology and Metabolism Population Sciences Institute, Tehran University of Medical Sciences, Tehran, IR Iran \\ ${ }^{8}$ Department of Epidemiology, Iran University of Medical Sciences, Tehran, IR Iran \\ ${ }^{*}$ Corresponding Authors: Mostafa Qorbani, Department of Community Medicine, School of Medicine, Alborz University of Medical Sciences, Karaj, IR Iran. Tel: +98-26328891354, \\ E-mail: mqorbani1379@yahoo.com; Hossein Fakhrzadeh, Elderly Health Research Center, Endocrinology and Metabolism Population Sciences Institute, Tehran University of \\ Medical Sciences, Tehran, IR Iran. Tel:+98-2188913543, Fax:+98-2188913543, E-mail: fakhrzad@sina.tums.ac.ir
}

Received 2014 October 20; Revised 2015 April 30; Accepted 2015 June 15.

\begin{abstract}
Context: Metabolic syndrome (MetS) increases the risk of most non-communicable diseases; gathering information about its prevalence can be very effective in formulating preventive strategies for metabolic diseases. There are many different studies about the prevalence of MetS in Iran, but the results and the study populations of these studies are very different; therefore, it is very important to have an overall estimation of its prevalence in Iran.

Objectives: This study systematically reviewed the findings of all available studies on MetS in the adult Iranian population and estimated the overall prevalence of MetS in this population.

Data Sources: International databases (Scopus, ISI Web of Science, and PubMed) were searched for papers published from January, 2000 to December, 2013 using medical subject headings (MeSH), Emtree, and related keywords (metabolic syndrome, dysmetabolic syndrome, cardiovascular syndrome, and insulin resistance syndrome) combined with the words "prevalence" and "Iran." The Farsi equivalent of these terms and all probable combinations were used to search Persian national databases (IranMedex, Magiran, SID, and Irandoc).

Study Selection: All population-based studies and national surveys that reported the prevalence of MetS in healthy Iranian adults were included.

Data Extraction: After quality assessment, data were extracted according to a standard protocol. Because of between-study heterogeneity, data were analyzed by the random effect method.

Results: We recruited the data of 27 local studies and one national study. The overall estimation of MetS prevalence was 36.9\% (95\% CI: 32.7 - 41.2\%) based on the Adult Treatment Panel III (ATP III) criteria, 34.6\% (95\% CI: 31.7 - 37.6\%) according to the International Diabetes Federation (IDF), and 41.5\% (95\% CI: 29.8 - 53.2\%) based on the Joint Interim Societies (JIS) criteria. The prevalence of MetS determined by JIS was significantly higher than those determined by ATP III and IDF. The prevalence of MetS was $15.4 \%$ lower in men than in women $(27.7 \%$ versus 43.1\%) based on the ATP III criteria, and it was 11.3\% lower in men based on the IDF criteria; however according to the JIS criteria, it was $8.4 \%$ more prevalent in men.

Conclusions: There is a high prevalence of MetS in the Iranian adult population, with large variations based on different measurement criteria. Therefore, prevention and control of MetS should be considered a priority.
\end{abstract}

Keywords:Metabolic Syndrome, Prevalence, Meta-Analysis, Iran

\section{Context}

Metabolic syndrome (MetS) (1) is a collection of interrelated disorders, namely obesity, dyslipidemia, hyperglycemia, and hypertension. Each MetS component increases the risk of cardiovascular disease (CVD), diabetes, and all-cause mortality. According to a study conducted by Gami et al., the synergistic effects of these disorders increase the risk of further disease and mortality much more than the sum of the risk increases from each com- ponent (2). However, other studies have provided different results (3-5). MetS increases total mortality from cardiovascular disease by 1.5 fold and risk for cardiovascular death by 2.5 fold (6). Moreover, individuals with MetS are five times more likely to develop type 2 diabetes (7). The main causes of MetS remain to be determined. However, it seems that abdominal obesity and insulin resistance are the key components (6-8). The most commonly used

Copyright (C) 2015, Iranian Red Crescent Medical Journal. This is an open-access article distributed under the terms of the Creative Commons Attribution-NonCommercial 4.0 International License (http://creativecommons.org/licenses/by-nc/4.0/) which permits copy and redistribute the material just in noncommercial usages, provided the original work is properly cited. 
definitions for MetS are those provided by the world health organization (WHO), the National Cholesterol Education Program-Adult Treatment Panel III (NCEP-ATP III), the international diabetes federation (IDF), and the joint interim societies (JIS), as presented in following sections. MetS is a common disorder, and given that its predisposing factors including obesity, sedentary lifestyle, and exposure to some environmental factors are escalating in many countries, the incidence of MetS is increasing as well (9). Therefore, MetS is now an emerging health problem at the public and individual levels. Because programs for primary prevention of non-communicable diseases emphasize appropriate evaluation and management of risk factors, (10) gathering reliable information about the prevalence of MetS in various populations can be very effective in the planning and use of preventive strategies for such diseases.

The prevalence of MetS is not only influenced by excess weight but also by ethnic predisposition, gender, age, race, cultural and lifestyle habits, and environmental factors; thus, its prevalence has large variations in different societies (11, 12). Grundy reported that between 20\% and 30\% of the adult population in most countries have MetS (13). Asians have an ethnic predisposition to MetS $(14,15)$, and it is of special concern for Middle Eastern populations, which are predicted to experience the greatest global burden of diabetes by 2020 (14). As a country in this region, Iran is reported to have one of the highest prevalence rates of MetS worldwide (16). The nationwide prevalence of MetS is reported to be $35.6 \%$ based on ATP III criteria (14). In metropolitan Tehran, $42 \%$ of women and $24 \%$ of men have MetS, with a total age-standardized prevalence of $33.7 \%$ (16). Iran is a vast country with about 70 million people and different ethnicities including Turkish, Kurdish, Arab, Fars, Turkmen, and Baluch living in different regions of the country. The difference in their cultures, socioeconomic status, lifestyle habits, and environmental factors may cause variation in the prevalence of MetS (17-23), so it is very important to have an overall estimation of its prevalence in Iran.

\section{Objectives}

This study aimed to systematically review the findings of available studies and to combine them to estimate the overall prevalence of MetS in Iran. The other objective of this study was to explore potential sources of heterogeneity in the study findings.

\section{Data Sources}

The English-language medical literature was searched from January, 2000 to December, 2013 in Scopus, ISI Web of Science, and PubMed. Using medical subject headings (MeSH), Emtree, and related keywords, we searched for "metabolic syndrome," "dysmetabolic syndrome," "cardiovascular syndrome," and "insulin resistance syndrome" combined with "prevalence" and "Iran," including all subheadings. The Farsi equivalent of these terms and all probable combinations were used to search in
Persian databases (i.e., IranMedex, Magiran, SID, and Irandoc). Moreover, the references of selected citations and non-published national surveys were hand-searched. In addition, when articles had incomplete data, at least three e-mails were sent to corresponding authors.

\section{Study Selection}

All types of studies, including local and national surveys that reported the prevalence of MetS and were conducted in Iran were reviewed. However, the final review was limited to studies with random sampling on healthy adults and/or on the general population who were aged 18 years and over. The studies that were conducted on subjects with known health disorders were excluded. In the case of multiple publications from the same population, only the largest study was included. The STROBE (strengthening the reporting of observational studies in epidemiology) statement was used for quality control of the studies (24). The quality of studies was assessed according to variables related to the study objectives, characteristics of the study population, clearly explained inclusion/exclusion criteria, data collection method, as well as the validity, explicit findings, and appropriate data analysis methods of the studies. Non-qualified studies were excluded. Moreover, duplicated citations were not included.

\section{Data Extraction}

After determining the qualified papers, data were extracted according to a standard protocol. To improve accuracy and critical appraisal, data extraction was conducted by two independent researchers, and disputes between researchers were resolved by consensus. The following items were extracted from the studies:

General information: first author's name, study location, study date, publication date, definition used for MetS

Population characteristics: sex groups, mean age, and age range

Methodological information: sampling method, sample size, scope of study (urban, rural, or survey)

Study outcomes: reported prevalence of MetS extracted by sex (men, women, and total), and its 95\% confidence interval (CI) concerning the prevalence of MetS components.

\subsection{Statistical Analysis}

Prevalences are reported with 95\% confidence intervals (CI). A Chi-square-based Q test was used to analyze the heterogeneity of reported prevalences and was regarded to be statistically significant at $\mathrm{P}<0.1$. Tau-square $(\tau 2)$ was estimated (using the restricted likelihood method) as the indicator of heterogeneity. After using the heterogeneity test, we found significant variations between study findings; thus, in order to obtain better results, the random effect model was used to estimate the overall prevalence of MetS in Iran. The findings are described in forest plots (the point estimations and their $95 \% \mathrm{CI}$ ). In the next step, 
meta-regression was used to check the effects of age and publication date as possible sources of heterogeneity among the study findings. The analyses were conducted with STATA software, version 11.0.

\section{Results}

In our primary search, and after removing duplicates, we found 379 relevant articles. After excluding non-eligible studies, we recruited the data of 27 local studies and one national study, which included all provinces of Iran. The details of our study selection method are shown in Figure 1. In each selected study, the prevalence of MetS was reported according to different criteria. Among the 28 studies, we found 21 reports given according to ATP III (including 12 based on ATP III (25) and nine based on modified ATP III (26)), six reports according to IDF (7), and one report according to the Iranian modified IDF (27), one report according to the WHO criteria, (28) and five reports according to the JIS criteria (29).

The findings of this systematic review are summarized in Table 1. For data analysis, we merged the ATP III and modified ATP III reports. The reports of IDF and Iranian modified IDF (27) were also merged; the meta-analysis was performed on three groups of reports: ATP III, IDF, and JIS. The only study that had used the WHO criteria for MetS was excluded from the analysis. If an article reported the prevalence of MetS according to both ATP III and modified ATP III, both were used as separate reports in the analysis.

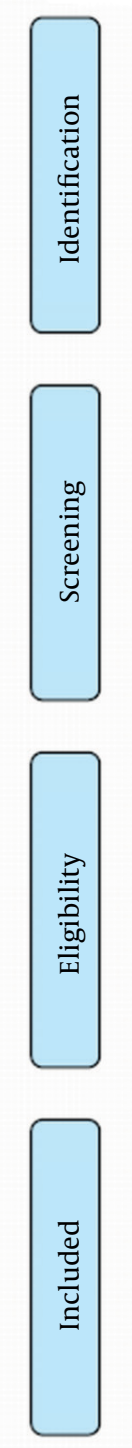

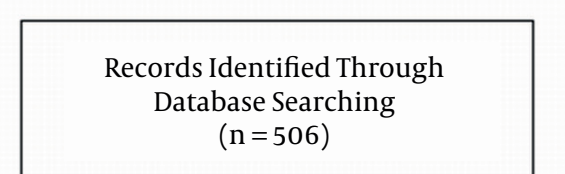
$(\mathrm{n}=506)$
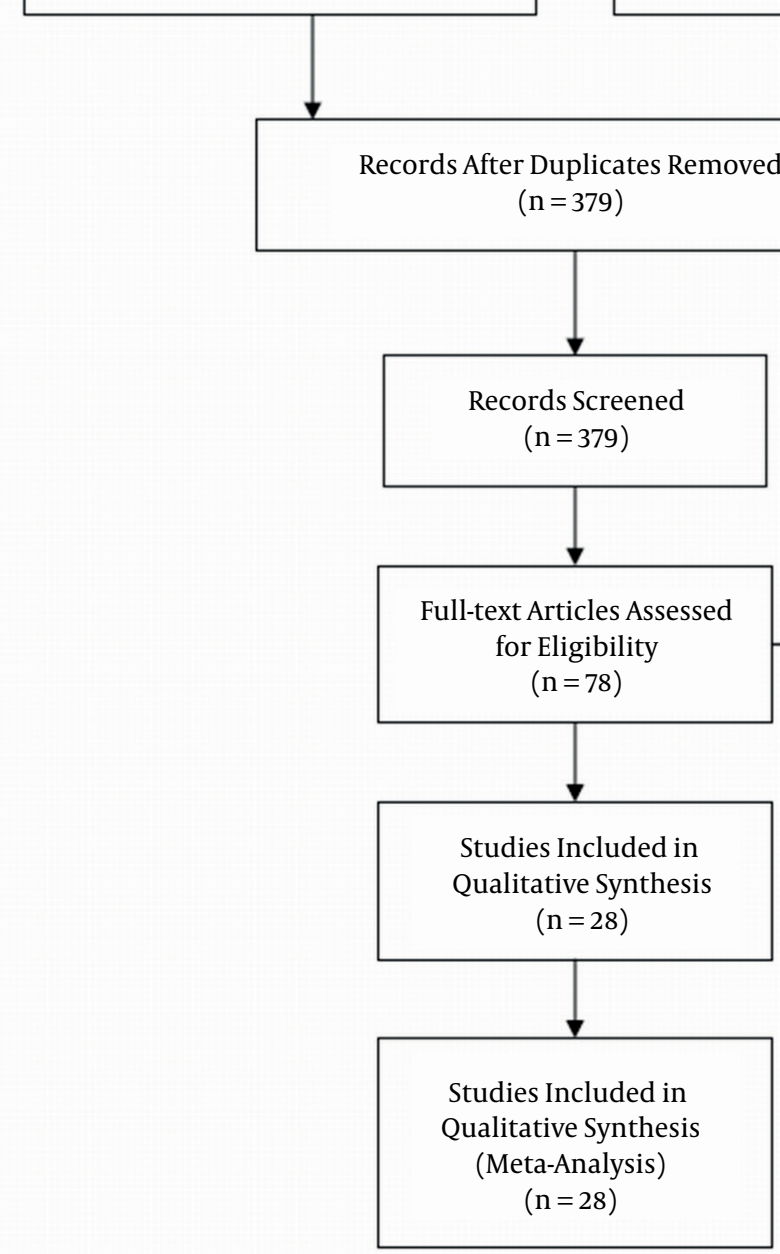

Additional Records Identified Through Other Sources $(\mathrm{n}=0)$

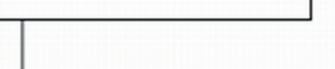

Records Excluded ( $\mathrm{n}=301$ )

- 50 Studies Were on Adolescents or Children

- 108 Studies Were on Subjects With Diseases

- 143 Studies Were Unrelated

Full-text Articles Excluded, With Reasons $(n=50)$

- 30 Studies Were Excluded Because of the Same Target Population

- 20 Studies Didn't Have Random Sampling

Figure 1. Flow Diagram of the Study Selection Process 


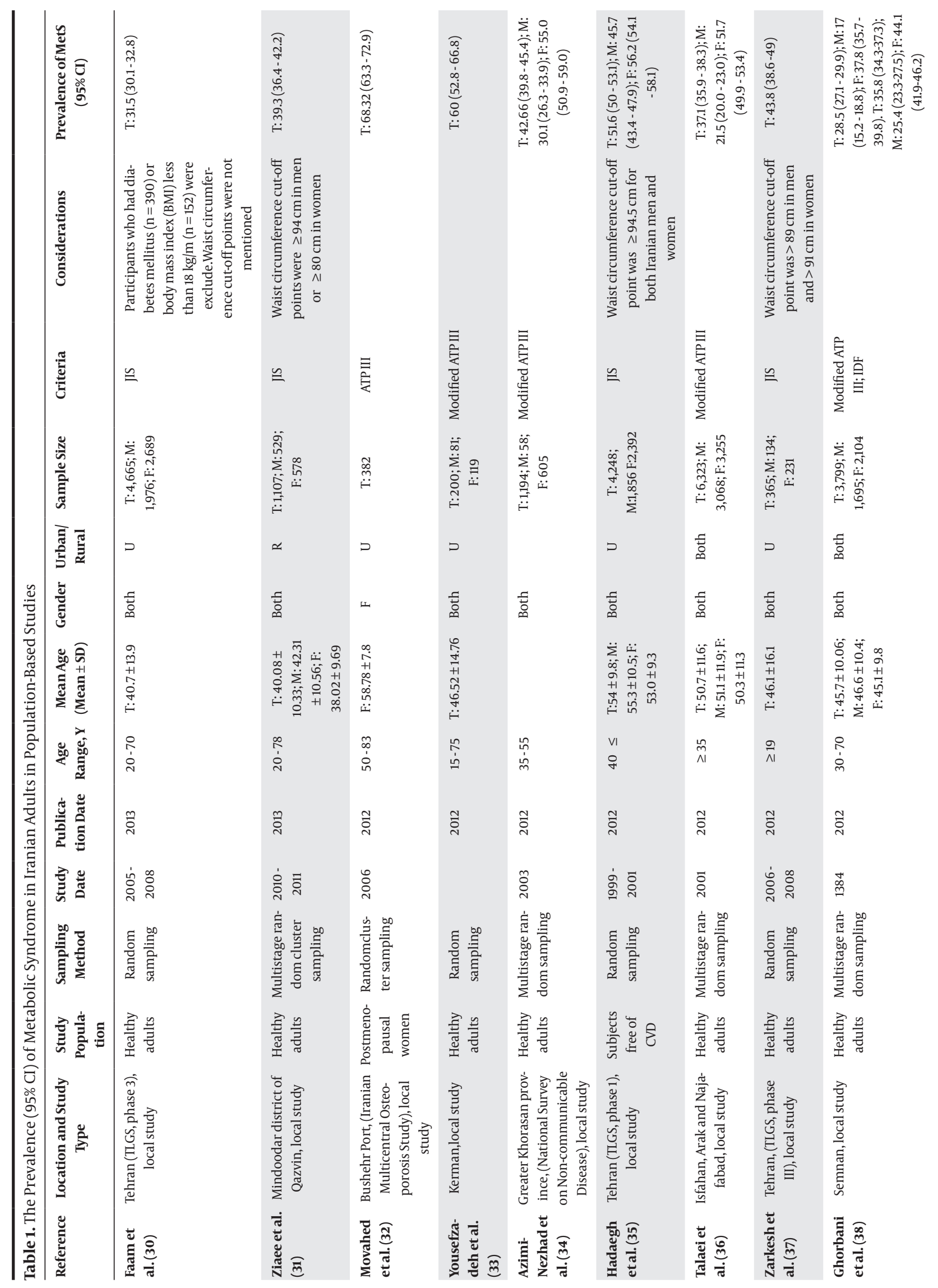




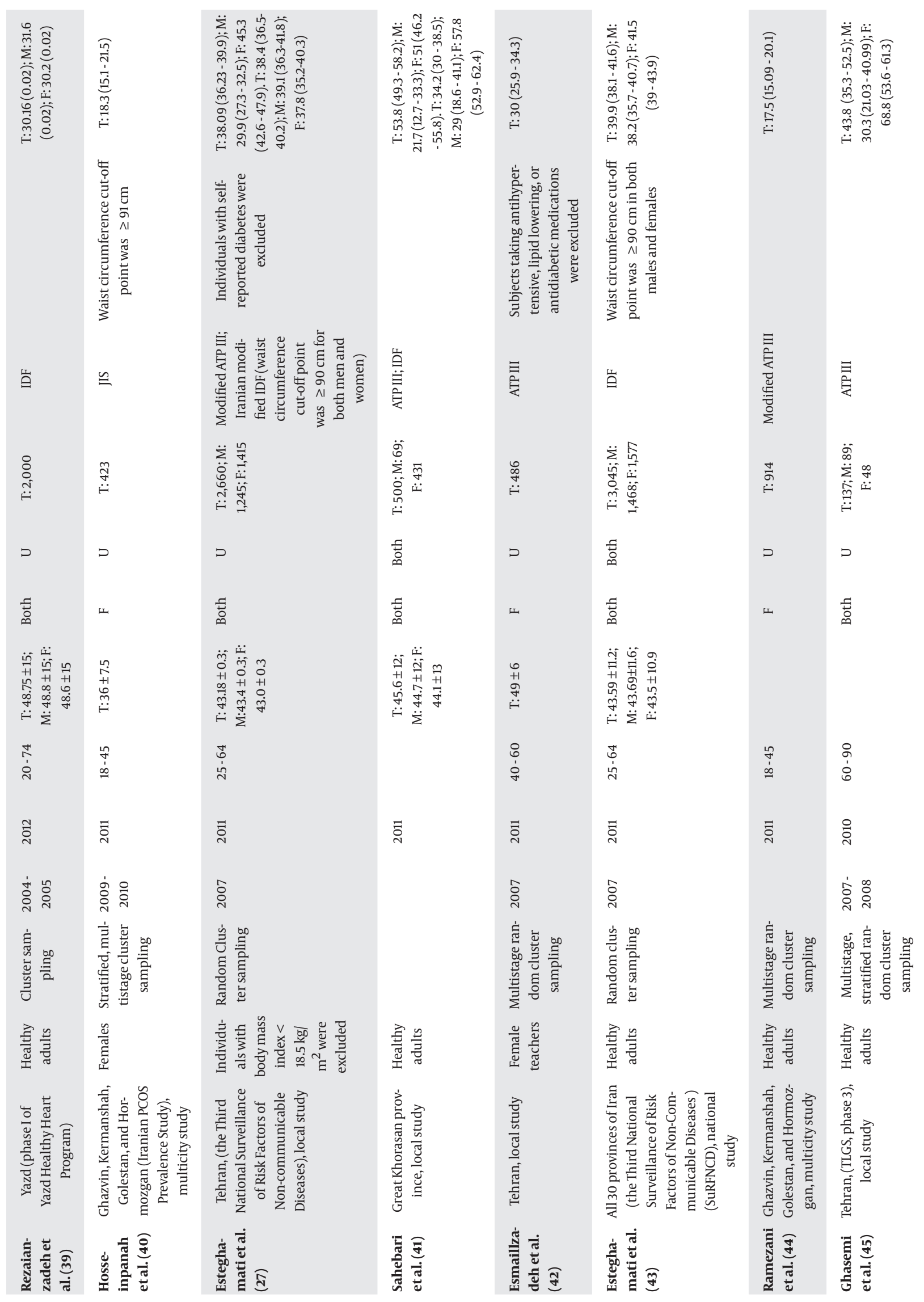




\begin{tabular}{|c|c|c|c|c|c|c|c|c|c|c|}
\hline 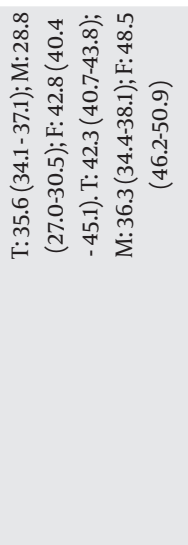 & 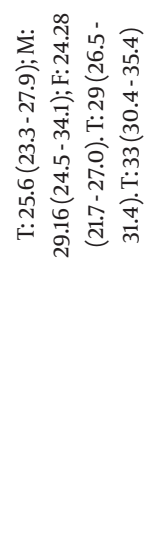 & 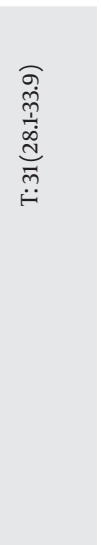 & 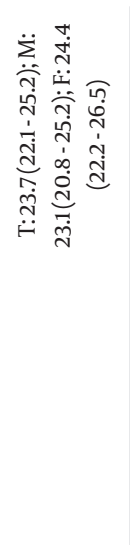 & 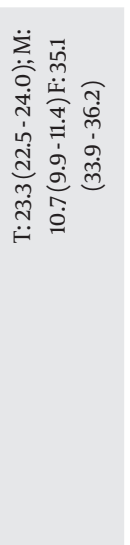 & 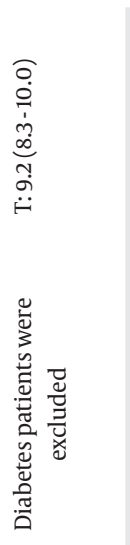 & 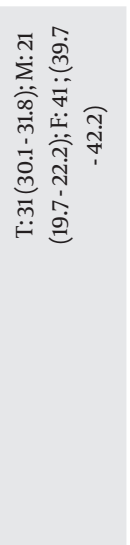 & 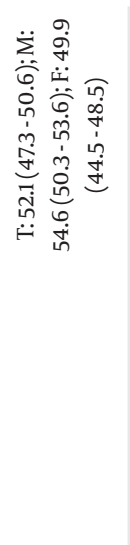 & 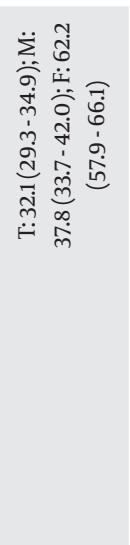 & 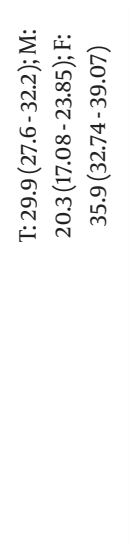 & 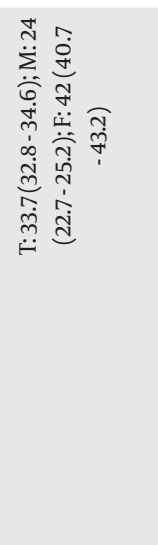 \\
\hline 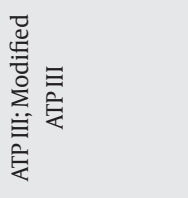 & 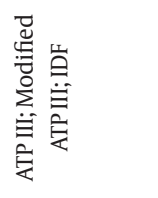 & $\underset{E}{E}$ & 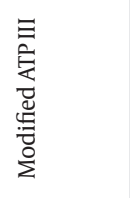 & 志 & 柿 & 嵌 & 恶 & 戛 & 志 & 志 \\
\hline 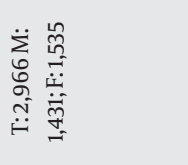 & 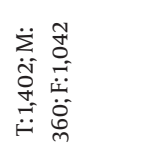 & $\underset{\stackrel{H}{H}}{\stackrel{H}{H}}$ & 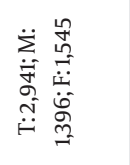 & 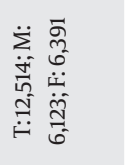 & 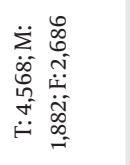 & 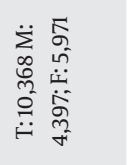 & 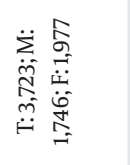 & 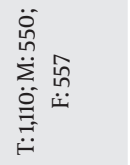 & 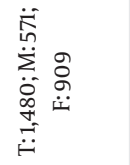 & 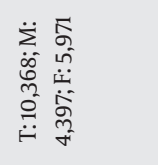 \\
\hline పే & $\simeq$ & $D$ & $\supset$ & Еँ & $\supset$ & $\supset$ & 芯 & $D$ & $D$ & $\supset$ \\
\hline 咅 & 咅 & ш & 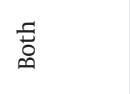 & 咅 & 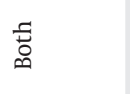 & 志 & 咅 & 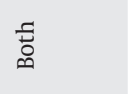 & 咅 & Е \\
\hline 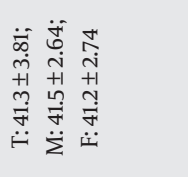 & 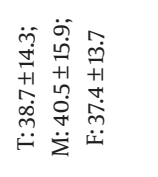 & 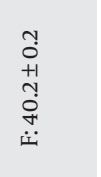 & & & 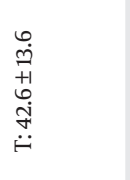 & 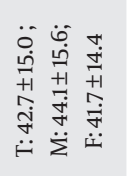 & & 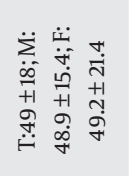 & 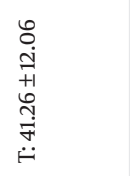 & \\
\hline $\begin{array}{l}\vec{b} \\
\dot{d}\end{array}$ & $\begin{array}{l}\stackrel{\circ}{\circ} \\
\dot{\infty}\end{array}$ & $\begin{array}{l}\dot{n} \\
\dot{m} \\
\dot{m}\end{array}$ & $\stackrel{\sim}{\wedge}$ & $\stackrel{9}{\wedge}$ & $\underset{\wedge}{\wedge}$ & $\underset{\wedge}{\stackrel{\sim}{\Lambda}}$ & $\stackrel{\stackrel{n}{N}}{\wedge}$ & $\begin{array}{l}\text { ते } \\
\dot{i} \\
\dot{i}\end{array}$ & $\begin{array}{l}\stackrel{+}{0} \\
\dot{\sim}\end{array}$ & 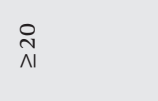 \\
\hline ठे & 。े & \&ें & ڤे & 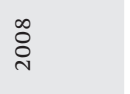 & 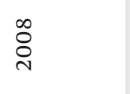 & ڤે̀ & ڤે̀े & ঃั & ঃั & ڤ̊̀̊ \\
\hline ڤ્ণ & 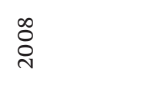 & & 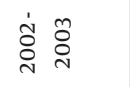 & 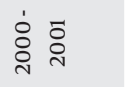 & 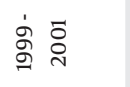 & बें Б̄ & 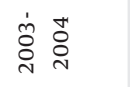 & 蒿 & ڤ̊̀ & 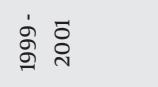 \\
\hline 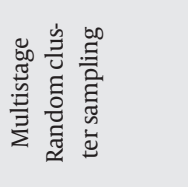 & 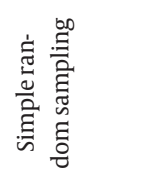 & 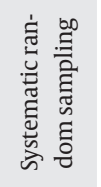 & 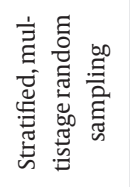 & 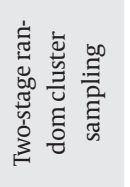 & 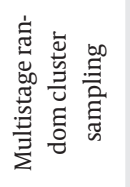 & 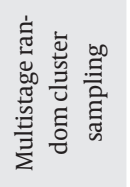 & 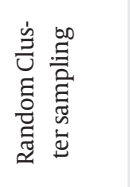 & 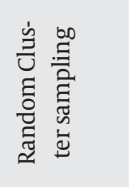 & 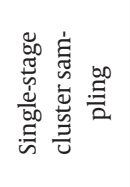 & 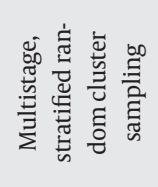 \\
\hline 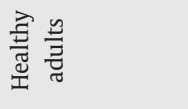 & 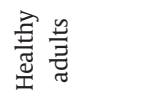 & 龸 & 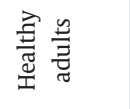 & 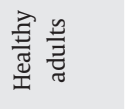 & 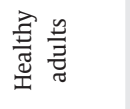 & 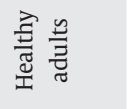 & 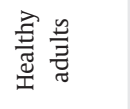 & 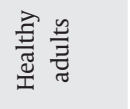 & 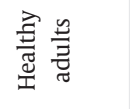 & 离总 \\
\hline 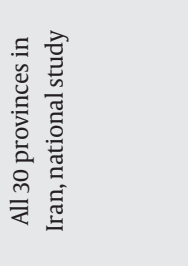 & 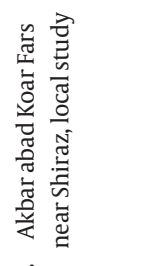 & 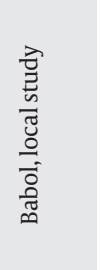 & 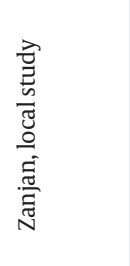 & 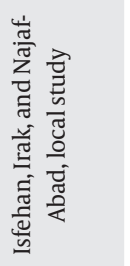 & 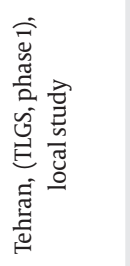 & 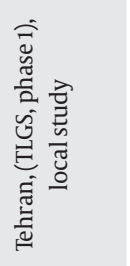 & 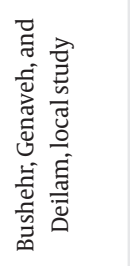 & 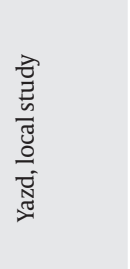 & 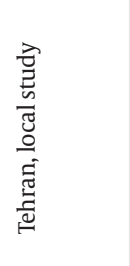 & 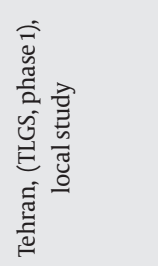 \\
\hline 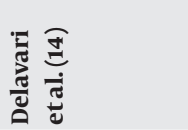 & 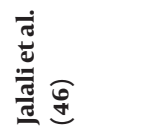 & 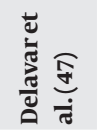 & 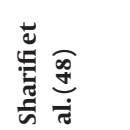 & 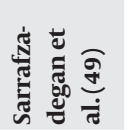 & 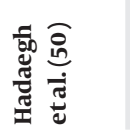 & 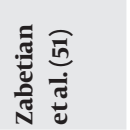 & 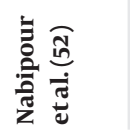 & 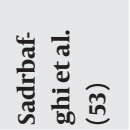 & 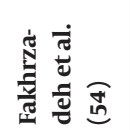 & 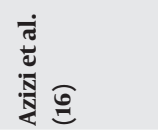 \\
\hline
\end{tabular}


Amirkalali B et al.

The total sample sizes of studies using the criteria of ATP III, IDF, and JIS were 54,043, 23,774, and 1,088, respectively (Table 2). For ATP III criteria, the maximum and minimum sample sizes were 12,514 (in Isfahan) and 137 (in Tehran), respectively. Maximum and minimum sample sizes for IDF were 10,368 and 486 (both in Tehran) and for JIS, they were 4,665 and 365 (both in Tehran), respectively. The overall estimation of MetS prevalence was 36.9\% (95\% CI: 32.7 - 41.2\%) according to ATP III, 34.6\% (95\% CI: 31.7 -
37.6\%) for IDF, and 41.5\% (95\% CI: 29.8 - 53.2\%) based on the JIS criteria (Table 2 and Figure 2). The prevalence of MetS measured by JIS was higher than those measured by the ATP III and IDF definitions (41.5\% versus $36.9 \%$ and $34.6 \%$ ); however, this difference was not statistically significant. Maximum and minimum prevalence rates of MetS were $60 \%$ and $23 \%$ based on the ATP III criteria, $40 \%$ and $30 \%$ for the IDF criteria, and 52\% and 31\% for the JIS criteria, respectively (Figure 2).

Table 2. The Overall Prevalence of Metabolic Syndrome in the Iranian Adult Population According to Different Criteria and Sex Using Random Effect Meta-Analysis of Data From Population-based Studies

\begin{tabular}{|c|c|c|c|c|}
\hline Criteria & Extracted articles (n) & Sample size (n) & Prevalence (\%) & CI 95\% \\
\hline \multicolumn{5}{|l|}{ ATP III } \\
\hline Male & 15 & 24,760 & 27.7 & $21.8-33.6$ \\
\hline Female & 19 & 32,046 & 43.1 & $37.9-48.4$ \\
\hline Total & 17 & 54,043 & 36.9 & $32.7-41.2$ \\
\hline \multicolumn{5}{|c|}{$\begin{array}{l}\text { Heterogeneity ATP III } \\
\text { (I-square) }\end{array}$} \\
\hline Male & $99.9 \%$ & $\mathrm{P}<0.001$ & & \\
\hline Female & $99.8 \%$ & $\mathrm{P}<0.001$ & & \\
\hline Total & $99.8 \%$ & $\mathrm{P}<0.001$ & & \\
\hline \multicolumn{5}{|l|}{ IDF } \\
\hline Male & 6 & 9,874 & 30.7 & $23.9-37.5$ \\
\hline Female & 6 & 12,498 & 42.0 & $37.4-46.6$ \\
\hline Total & 7 & 23,774 & 34.6 & $31.7-37.6$ \\
\hline \multicolumn{5}{|c|}{$\begin{array}{l}\text { Heterogeneity IDF } \\
\text { (I-square) }\end{array}$} \\
\hline Male & $99.6 \%$ & $\mathrm{P}<0.001$ & & \\
\hline Female & $99 \%$ & $\mathrm{P}<0.001$ & & \\
\hline Total & $98.9 \%$ & $\mathrm{P}<0.001$ & & \\
\hline \multicolumn{5}{|l|}{ JIS } \\
\hline Male & 1 & 1,856 & 45.7 & $44.6-46.8$ \\
\hline Female & 2 & 2,815 & 37.3 & $32.4-42.2$ \\
\hline Total & 4 & 10,385 & 41.5 & $29.8-53.2$ \\
\hline \multicolumn{5}{|c|}{$\begin{array}{l}\text { Heterogeneity JIS } \\
\text { (I-square) }\end{array}$} \\
\hline Male & - & & & \\
\hline Female & $99.9 \%$ & $\mathrm{P}<0.001$ & & \\
\hline Total & $99.8 \%$ & $\mathrm{P}<0.001$ & & \\
\hline
\end{tabular}


Study

ID

$\mathrm{ES}(95 \% \mathrm{CI})$

\section{ATP III}

Sarrafzadegan et al. (2008)

Talaei et al. (2012)

Esteghamati et al. (2011)

Jalali et al. (2009)

Nabipour et al. (2007)

Ghorbani et al. (2012)

Delavari et al. (2009)

Ghasemi et al. (2010)

Azizi et al. (2003)

Delavari et al.(2009)

Sadrbafghi et al. (2006)

Saheban et al. (2011)

Yousefzadeh et al. (2012)

Sharifi et al. (2009)

Jalali et al. (2009)

Azimi-Nezhad et al. (2012)

Fakhrzadeh et al. (2009)

Subtotal (l.squared $=99.8 \%, \mathrm{p}=0.000$ )

IDF

Esteghamati et al. (2011)

Esteghamati et al.(2011)

Zabetian et al. (2007)

Sahebari et al. (2011)

Rezaian zadeh et al. (2012)

Ghorbani et al. (2012)

Jalali et al. (2009)

Subtotal $($ l.squared $=98.9 \%, p=0.000$ )

Jis

Ziaee et al. (2013)

Zarkesh et al. (2012)

Faam et al. (2013)

Hadaegh et al. (2012)

Subtotal $($ l.squared $=99.8 \%, p=0.000)$

.

Overall $(\mathrm{l}$. Squared $=99.8 \%, \mathrm{p}=0.000$ )

NOTE: Weights are from Random Effects Analvsis

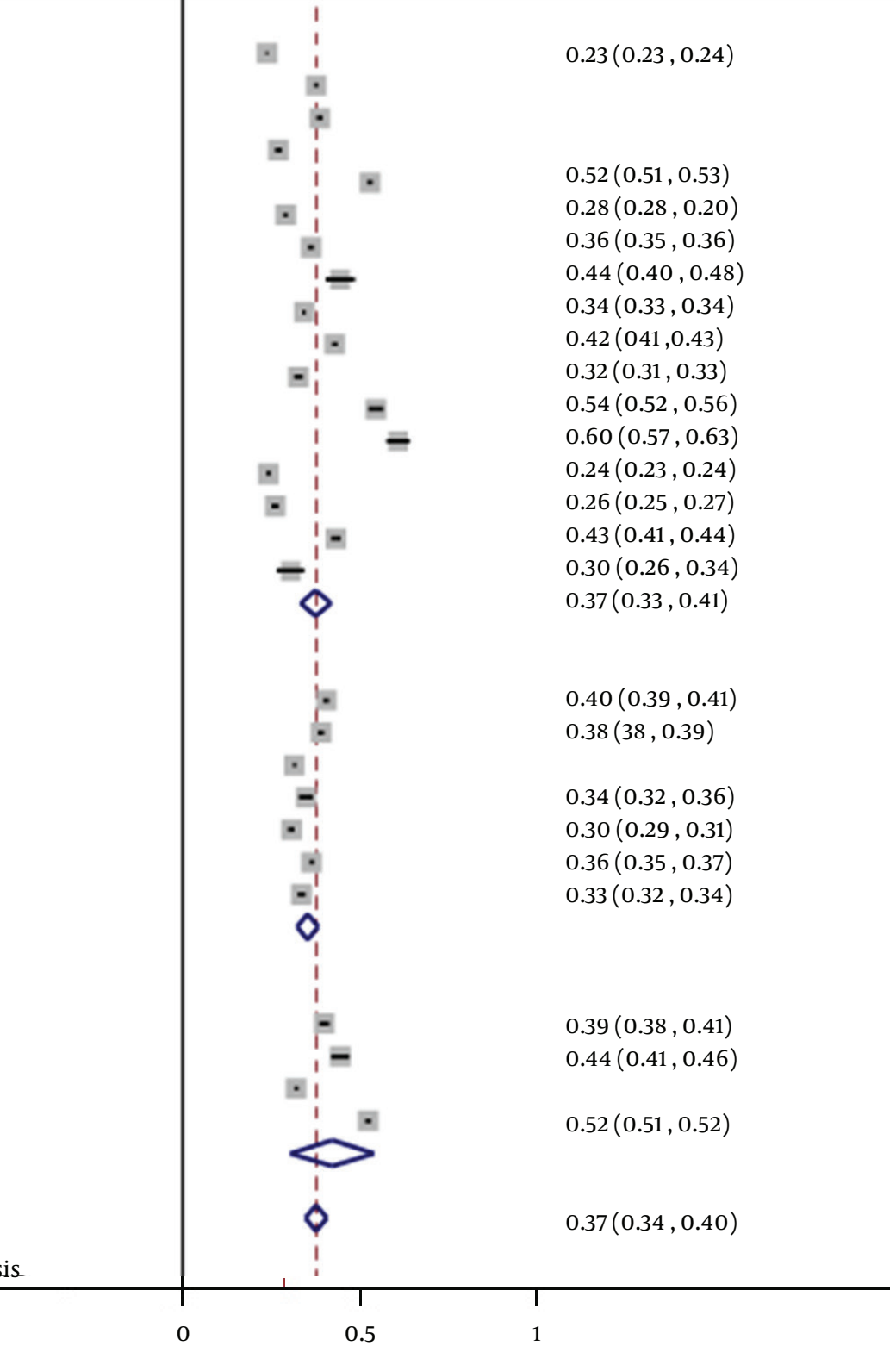

Figure 2. Forest Plot of the Prevalence of Metabolic Syndrome in the Iranian Adult Population

According to the ATP III criteria, the prevalence of MetS was significantly (15.4\%) lower in men than in women (27.7\% versus $43.1 \%$, respectively). The same trend was obtained for the IDF definition, which found MetS to be $11.3 \%$ less prevalent in men than in women (30.7\% versus $42.0 \%$, respectively). However, the reverse was true for the 


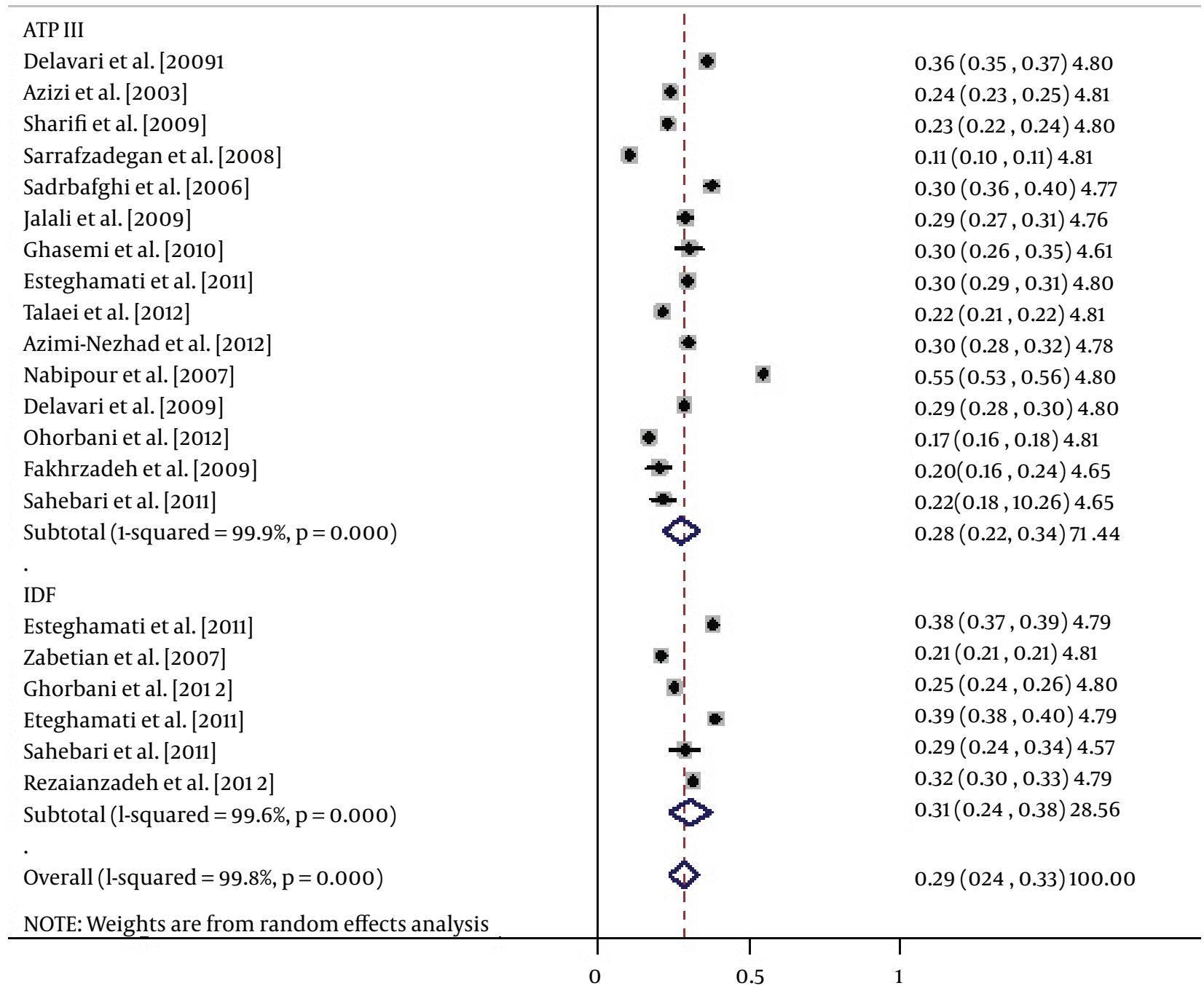

Figure 3. Forest Plot of the Prevalence of Metabolic Syndrome in the Iranian Male Adult Population

JIS definition, which showed a significantly higher (8.4\%) prevalence in men than in women (45.7\% versus $37.3 \%$, respectively) (Table 2, Figures 3 and 4 ).

The results of the meta-regression show that the main source of heterogeneity in findings was the mean age of participants. The results show that by each year increase in the mean age of individuals after the age of 18 , the prevalence of MetS increased by $0.004 \%$ (coefficient:
$0.0048792, \mathrm{P}=0.005)$

Nine studies reported the prevalence of MetS components according to different criteria (Table 3). Among these studies, in six the prevalence of components was calculated in subjects with MetS. Most of the subjects with MetS had three components (54.7\% - 95\%). The prevalences of four and five components in MetS subjects were $0.6-34 \%$ and $0-11.8 \%$, respectively. 
Study

ID

$\mathrm{ES}(95 \% \mathrm{CI})$

$\%$

Weight

\section{ATP III}

Sadrbafghi et al. [2006]

Ramezani et al. [2011]

Nabipour et al. [2007]

Delavar et al. [2009]

Jalali et al. [2009]

Movahed et al. [2012]

Delavari et al. [2009]

Talaei et al. [2012]

Ghorbani et al. [2012]

Delavari et al. [2009]

Sharifi et al. [2009]

Esmailzadeh et al. [2011]

Esteghamati et al. [2011]

Sahebari et al. [2011]

Azimi-Nezhad et al. [2012]

Fakhrzadeh et al. [2009]

Sarrafzadegan et al. [2030]

Ghasemi et al. [2010]

Azizi et al. [2003]

Subtotal (l-squared \%99.8, $\mathrm{p}=0.000$ )

IDF

Esteghamati et al [2011]

Ghorbani et al [2012]

Zabetian et al [2007]

Sahebari et al [2011]

Rezaianzadeh et al [2012]

Esteghamati et al [2011]

Subtotal (I-squared $=\% 99.0, \mathrm{p}=0.030$ )

Overall (I-squared $=$ gOE\%7, p = 0.000)

NOTE: Weight are from random effects analysis.
$0.62(0.60,0.64) 4.00$

$0.17(0.17,0.18) 4.03$

$0.50(0.49,0.51) 4.03$

$0.31(0.30,0.32) 4.02$

$0.24(0.23,0.25) 4.03$

$0.68(0.66,0.70) 3.99$

$049(0.47,0.50) 4.02$

$0.52(0.51,0.53) 4.03$

$0.38(0.37,0.39) 4.03$

$0.43(0.42,0.44) 4.02$

$0.24(0.23,0.25) 4.03$

$0.30(0.28,0.32) 4.00$

$0.45(0.44,0.47) 4.02$

$0.51(0.49,0.53) 3.98$

$0.55(0.53,0.57) 4.00$

$0.36(0.32,0.40) 3.89$

$0.35(0.35,0.36) 4.03$

$0.69(0.63,0.75) 3.70$

$0.42(0.41,043) 4.03$

$0.43(0.38,0.48) 75.89$

$0.41(0.40,0.43) 4.02$

$0.44(0.43,0.45) 4.03$

$0.41(0.40,0.42) 4.03$

$0.58(0.55,0.60) 3.99$

$0.30(0.29,0.32) 4.02$

$0.38(0.37,0.39) 4.02$

$0.42(0.37,0.47) 24.11$

$0.43(0.39,0.47) 100.00$

Figure 4. Forest Plot of the Prevalence of Metabolic Syndrome in the Iranian Female Adult Population

\begin{tabular}{|c|c|c|c|c|c|c|c|c|c|c|c|c|}
\hline Reference & $\begin{array}{l}\text { Location } \\
\text { and type of } \\
\text { study }\end{array}$ & $\begin{array}{l}\text { Study } \\
\text { popula- } \\
\text { tion }\end{array}$ & $\begin{array}{l}\text { Sampling } \\
\text { method }\end{array}$ & $\begin{array}{c}\text { Study } \\
\text { date }\end{array}$ & $\begin{array}{l}\text { Publica- } \\
\text { tion date }\end{array}$ & $\begin{array}{l}\text { Age range } \\
\text { (years) }\end{array}$ & $\begin{array}{l}\text { Mean age } \\
\text { (mean } \pm \\
\text { SD) }\end{array}$ & Sex & $\begin{array}{c}\text { Urban/ } \\
\text { rural }\end{array}$ & $\begin{array}{l}\text { Sample } \\
\text { size }\end{array}$ & Criteria & $\begin{array}{l}\text { Prevalence of MetS com- } \\
\text { ponents }(\%)\end{array}$ \\
\hline $\begin{array}{l}\text { Tohidi et } \\
\text { al.(44) }\end{array}$ & $\begin{array}{l}\text { Ghazvin, } \\
\text { Kerman- } \\
\text { shah, } \\
\text { Golestan, } \\
\text { and Hor- } \\
\text { mozgan, } \\
\text { multicity } \\
\text { study }\end{array}$ & $\begin{array}{l}\text { Healthy } \\
\text { adults }\end{array}$ & $\begin{array}{l}\text { Multistage } \\
\text { random } \\
\text { cluster } \\
\text { sampling }\end{array}$ & & 2011 & $18-45$ & & $\mathrm{~F}$ & $\mathrm{U}$ & T: 914 & $\begin{array}{l}\text { Modified } \\
\text { ATP III }\end{array}$ & $\begin{array}{c}3 \text { components: } 11.4 ; 4 \\
\text { components: } 5.1 ; 5 \text { compo- } \\
\text { nents: } 1\end{array}$ \\
\hline
\end{tabular}


Amirkalali B et al.

\begin{tabular}{|c|c|c|c|c|c|c|c|c|c|c|c|c|}
\hline $\begin{array}{l}\text { Fakhrza- } \\
\text { deh et al. } \\
(54)\end{array}$ & $\begin{array}{l}\text { Isfahan (co- } \\
\text { hort study), } \\
\text { local study }\end{array}$ & $\begin{array}{l}\text { Healthy } \\
\text { adults }\end{array}$ & $\begin{array}{l}\text { Random } \\
\text { stratified } \\
\text { sampling }\end{array}$ & & 2011 & $43-82$ & $56.42 \pm 9.52$ & Both & Both & $\begin{array}{l}\mathrm{T}: 468 \\
\mathrm{M}: 236 \\
\mathrm{~F}: 232\end{array}$ & ATP III & $\begin{array}{c}3 \text { components: } 55.2 ; 4 \\
\text { components: } 34 ; 5 \text { compo- } \\
\text { nents: } 10.8\end{array}$ \\
\hline $\begin{array}{l}\text { Jalali et } \\
\text { al.(46) }\end{array}$ & $\begin{array}{l}\text { Akbar abad } \\
\text { Koar Fars } \\
\text { near Shiraz, } \\
\text { local study }\end{array}$ & $\begin{array}{l}\text { Healthy } \\
\text { adults }\end{array}$ & $\begin{array}{l}\text { Simple } \\
\text { random } \\
\text { sampling }\end{array}$ & $\begin{array}{l}2008 \\
(1387)\end{array}$ & 2009 & $18-90$ & $\begin{array}{c}\mathrm{T}: 38.7 \pm 14.3 \\
\mathrm{M}: 40.5 \pm \\
15.9 ; \mathrm{F}: 37.4 \\
\quad \pm 13.7\end{array}$ & Both & $\mathrm{R}$ & $\begin{array}{l}\mathrm{T}: 1,402 \\
\mathrm{M}: 360 \\
\mathrm{~F}: 1,042\end{array}$ & $\begin{array}{l}\text { ATP III; } \\
\text { Modified } \\
\text { ATP III; } \\
\text { IDF }\end{array}$ & $\begin{array}{l}\text { Total, } 3 \text { components: } 95 ; \\
4 \text { components : } 0.6 ; 5 \\
\text { components: } 4.5 ; \text { male, } 3 \\
\text { components: } 99 ; 4 \text { compo- } \\
\text { nents: } 0 ; 5 \text { components:1; } \\
\text { female, } 3 \text { components: } \\
\text { 93.4; } 4 \text { components: } 0.6 \text {; } \\
5 \text { components: } 6 \text {. Total, } \\
3 \text { components: } 66.3 ; 4 \\
\text { components: } 27.1 ; 5 \text { compo- } \\
\text { nents: } 6.7 ; \text { male, } 3 \text { compo- } \\
\text { nents: } 71.4 ; 4 \text { components: } \\
\text { 26.1; } 5 \text { components: } 2.5 ; \\
\text { female, } 3 \text { components: } \\
\text { 64.1; } 4 \text { components: } 27.5 ; \\
5 \text { components: } 8.4 \text {. Total,3 } \\
\text { components: } 54.7 ; 4 \text { com- } \\
\text { ponents: } 33.4 ; 5 \text { compo- } \\
\text { nents: } 11.8 ; \text { Male, } 3 \text { compo- } \\
\text { nents: } 38.4 ; 4 \text { components: } \\
44.8 ; 5 \text { components: } 16.8 ; \\
\text { Female, } 3 \text { components: } \\
\text { 59; } 4 \text { components: } 30.5 ; 5 \\
\text { components: } 10.5\end{array}$ \\
\hline $\begin{array}{l}\text { Delavar } \\
\text { et al. ( } 47)\end{array}$ & $\begin{array}{c}\text { Babol, local } \\
\text { study }\end{array}$ & $\begin{array}{c}\text { Female } \\
\text { adults }\end{array}$ & $\begin{array}{l}\text { Systematic } \\
\text { random } \\
\text { sampling }\end{array}$ & & 2009 & $30-50$ & $\mathrm{~F}: 40.2 \pm 0.2$ & $\mathrm{~F}$ & $\mathrm{U}$ & $\mathrm{T}: 944$ & ATP III & $\begin{array}{l}1 \text { component: } 30.8 ; 2 \text { com- } \\
\text { ponents: } 28.9 ; 3 \text { compo- } \\
\text { nents: } 22.6 ; 4 \text { components: } \\
\text { 7.4; } 5 \text { components: } 0.8\end{array}$ \\
\hline $\begin{array}{l}\text { Sharifi et } \\
\text { al. (48) }\end{array}$ & $\begin{array}{l}\text { Zanjan, lo- } \\
\text { cal study }\end{array}$ & $\begin{array}{l}\text { Healthy } \\
\text { adults }\end{array}$ & $\begin{array}{l}\text { Stratified, } \\
\text { multistage } \\
\text { random } \\
\text { sampling }\end{array}$ & $\begin{array}{c}2002- \\
2003\end{array}$ & 2009 & $>20$ & & Both & $\mathrm{U}$ & $\begin{array}{l}\text { T:2,941; } \\
\text { M:1,396; } \\
\text { F: } 1,545\end{array}$ & $\begin{array}{l}\text { Modified } \\
\text { ATP III }\end{array}$ & $\begin{array}{c}3 \text { components: } 75.6 ; 4 \\
\text { components: } 24.4 ; 5 \text { com- } \\
\text { ponents: } 0\end{array}$ \\
\hline $\begin{array}{l}\text { Nabipour } \\
\text { et al.(52) }\end{array}$ & $\begin{array}{l}\text { Bushehr, } \\
\text { Genaveh, } \\
\text { and Deilam, } \\
\text { local study }\end{array}$ & $\begin{array}{l}\text { Healthy } \\
\text { adults }\end{array}$ & $\begin{array}{l}\text { Random } \\
\text { cluster } \\
\text { sampling }\end{array}$ & $\begin{array}{l}2003- \\
2004\end{array}$ & 2007 & $\geq 25$ & & Both & Both & $\begin{array}{l}\text { T:3,723; } \\
\text { M:1,746; } \\
\text { F:1,977 }\end{array}$ & ATP III & $\begin{array}{l}\text { 0 components: } 4.0 ; 1 \text { com- } \\
\text { ponent:15.1; } 2 \text { components: } \\
28.7 ; 3 \text { components: } 30.8 ; 4 \\
\text { components: } 17.7 ; 5 \text { compo- } \\
\text { nents: } 3.6\end{array}$ \\
\hline $\begin{array}{l}\text { Sadrbaf- } \\
\text { ghi et al. } \\
(53)\end{array}$ & $\begin{array}{l}\text { Yazd, local } \\
\text { study }\end{array}$ & $\begin{array}{l}\text { Healthy } \\
\text { adults }\end{array}$ & $\begin{array}{l}\text { Random } \\
\text { cluster } \\
\text { sampling }\end{array}$ & $\begin{array}{l}2004 \\
(1383)\end{array}$ & 2006 & $20-74$ & $\begin{array}{l}\text { T: } 49 \pm 18 \\
\text { M: } 48.9 \pm \\
15.4 ; \mathrm{F}: 49.2 \\
\quad \pm 21.4\end{array}$ & Both & $\mathrm{U}$ & $\begin{array}{l}\mathrm{T}: 1,110 \\
\mathrm{M}: 550 \\
\mathrm{~F}: 557\end{array}$ & ATP III & $\begin{array}{l}0 \text { components: } 19.2 ; 1 \text { com- } \\
\text { ponent: } 21.1 ; 2 \text { components: } \\
\text { 27.6; } 3 \text { components: } 20.8 ; 4 \\
\text { components: } 9 ; 5 \text { compo- } \\
\text { nents: } 2.3\end{array}$ \\
\hline $\begin{array}{l}\text { Fakhrza- } \\
\text { deh et al. } \\
(54)\end{array}$ & $\begin{array}{l}\text { Tehran, lo- } \\
\text { cal study }\end{array}$ & $\begin{array}{l}\text { Healthy } \\
\text { adults }\end{array}$ & $\begin{array}{l}\text { Single stage } \\
\text { cluster } \\
\text { sampling }\end{array}$ & 2003 & 2006 & $25-64$ & $\begin{array}{c}\mathrm{T}: 41.26 \pm \\
12.06\end{array}$ & Both & $\mathrm{U}$ & $\begin{array}{l}\text { T:1,480; } \\
\text { M:571; F: } \\
\quad 909\end{array}$ & ATP III & $\begin{array}{l}0 \text { component: } 12 ; 1 \text { compo- } \\
\text { nent: } 29 ; 2 \text { components: } \\
\text { 29.1;3 components: } 22.7 ; 4 \\
\text { components: } 7.1 ; 5 \text { compo- } \\
\text { nents: } 0.2\end{array}$ \\
\hline $\begin{array}{l}\text { Azizi et al. } \\
\text { (16) }\end{array}$ & $\begin{array}{l}\text { Tehran, } \\
\text { (TLGS, } \\
\text { phase 1), } \\
\text { local study }\end{array}$ & $\begin{array}{l}\text { Healthy } \\
\text { adults }\end{array}$ & $\begin{array}{l}\text { Multistage } \\
\text { stratified } \\
\text { random } \\
\text { cluster } \\
\text { sampling }\end{array}$ & $\begin{array}{c}1999- \\
2001\end{array}$ & 2003 & $\geq 20$ & & Both & $\mathrm{U}$ & $\begin{array}{l}\text { T:10,368; } \\
\text { M: 4,397; } \\
\text { F: 5,971 }\end{array}$ & ATP III & $\begin{array}{c}\text { Total, } 3 \text { components: } \\
\text { 58; } 4 \text { components: } 33 ; 5 \\
\text { components: 9; Male, } 1 \\
\text { component: 29; } 2 \text { compo- } \\
\text { nents: 32;3 components: } \\
\text { 16; } 4 \text { components: 7; } 5 \\
\text { components: } 1 \text {; Female, } 1 \\
\text { component: } 28 ; 2 \text { compo- } \\
\text { nents: } 23 ; 3 \text { components: } \\
\text { 20; } 4 \text { components: } 14 ; 5 \\
\text { components: } 4\end{array}$ \\
\hline
\end{tabular}

a Abbreviations: F, female; M, male; T, total. 


\section{Conclusions}

Our findings show that the prevalence of MetS is relatively high in Iran according to all three definitions (ATP III: $36.9 \%$, IDF: $34.6 \%$, and JIS: $41.5 \%)$. These observed prevalence rates are noticeably higher than the estimated prevalence around the world, which is between $20 \%$ and $25 \%$ (7). The mean prevalence of MetS in Iran was found to be higher than in many other countries (e.g., Portugal [27.6\%], (55) Spain [26.6\%], (56) France [25\% in males and $15.3 \%$ in females], (57) and Italy [22\% in males and $18 \%$ in females]) (3). It was also higher than in the United States of America (22.9\%) (58). The prevalence of MetS in Iran is much closer to that in North Africa (30\%), (59) Asia-China (33.9\%), (60) Turkey (36.6\%), (60) and some Latin American countries such as Colombia (34.8\%) (61)and Venezuela (35.3\%) (62). Therefore it can be assumed that some reasons other than urbanization and inactivity have resulted in this relatively high prevalence of MetS in Iran. In a study conducted by Delavari et al., greater waist circumference values and lower HDL cholesterol have also been reported in Iranian communities than in Western populations, which support the idea of an ethnic predisposition of the Iranian community to MetS (14).

It is noteworthy to acknowledge that comparisons between Iran and other countries must be made with caution. First, because most of these studies were conducted in a small area or a city, they cannot be representative of the entire country. Thus, generalizing the estimated prevalence to a country is a point of concern. Second, it has been shown that MetS is highly age-dependent (63). This was also found in our study; the prevalence of MetS in the Iranian population increased around $0.004 \%$ by each year of age increase after the age of 18 . Therefore, even in a study with population-based sampling, comparing countries with different age pyramids might result in different prevalence rates, even with comparable risks of MetS. In recent years, the population of Iran has been growing older, and this might be one of the reasons for such a high prevalence of MetS in this country.

Another finding of this study was the significantly higher prevalence of MetS and its reverse sex distribution according to JIS compared to the other two definitions. According to the ATP III and IDF definitions, MetS prevalence was significantly higher in women (15.4\% and 11.3\% higher than the prevalence in men, respectively). However, based on the JIS criteria, MetS was 8.4\% more prevalent in men, which was also significant. The lack of consensus on MetS definitions and the cutoff points used for its components, especially regarding waist circumference, has resulted in these differences. In the JIS definition, the cutoff point for waist circumference is usually higher than those of ATP III and IDF for women and lower for men, which may have resulted in a higher prevalence of MetS being measured in men according to the JIS definition, and contrary to the ATP III and IDF definitions. These differences influence health policies and clinical practice, in which underestimation or overestimation may result in inappropriate distribution of health services. Barbosa et al. performed a cross-sectional study on 1,439 adults in Brazil and concluded that NCEP-ATP III (64) underestimated the prevalence of MetS, particularly in men. This study showed that MetS is a public health problem in Iran. It has a high prevalence and it is expected to have an increasing trend in coming years as the mean age of the Iranian population grows. Therefore, by implementing an appropriate screening and treatment system, many metabolic diseases (such as diabetes and cardiovascular disease) that are costly to society can be prevented.

The main limitation of this study is that estimated prevalences were not adjusted based on the size of the target populations. Regarding this point, the results of a cluster analysis method are much more reliable, but cluster sampling is not practical because it is very difficult and expensive to perform. It seems that meta-analysis could be an efficient substitute strategy.

The prevalence of MetS is relatively high in the Iranian adult population. The lack of consensus on MetS definitions has resulted in different reports of its prevalence. However, even considering the lowest prevalence of $34.6 \%$, the prevalence of MetS in Iran is considerably higher than the estimated prevalence around the world (20 - 25\%). Therefore, applying an appropriate screening and treatment system for MetS could prevent many chronic diseases that are costly to society.

\section{Footnotes}

Authors' Contribution:Study concept and design: Mostafa Qorbani, Hossein Fakhrzadeh; acquisition of data: Bahareh Amirkalali, Tahereh Samavat; analysis and interpretation of data: Mostafa Qorbani, Bahareh Amirkalali; drafting of the manuscript: Bahareh Amirkalali; critical revision of the manuscript for important intellectual content: Roya Kelishadi, Farhad Zamani, Farshad Sharifi and Saeid Safiri; statistical analysis: Mostafa Qorbani; administrative, technical, and material support: Hossein Fakhrzadeh, Hamid Asayesh; study supervision: Hossein Fakhrzadeh.

Funding/Support:This study was supported by the Endocrinology and Metabolism Population Sciences Institute at the Tehran University of Medical Sciences.

\section{References}

1. Reaven GM. Banting Lecture 1988. Role of insulin resistance in human disease. 1988. Nutrition. 1997;13(1):65. [PubMed: 9058458]

2. Gami AS, Witt BJ, Howard DE, Erwin PJ, Gami LA, Somers VK, et al. Metabolic syndrome and risk of incident cardiovascular events and death: a systematic review and meta-analysis of longitudinal studies. J Am Coll Cardiol. 2007;49(4):403-14. doi: 10.1016/j. jacc.2006.09.032. [PubMed: 17258085]

3. Giampaoli S, Stamler J, Donfrancesco C, Panico S, Vanuzzo D, Cesana $\mathrm{G}$, et al. The metabolic syndrome: a critical appraisal based on the CUORE epidemiologic study. Prev Med. 2009;48(6):525-31 doi:10.1016/j.ypmed.2009.03.017. [PubMed:19344739]

4. Scuteri A, Najjar SS, Morrell CH, Lakatta EG, Cardiovascular Health 
Amirkalali B et al.

S. The metabolic syndrome in older individuals: prevalence and prediction of cardiovascular events: the Cardiovascular Health Study. Diabetes Care. 2005;28(4):882-7. [PubMed: 15793190]

5. McNeill AM, Rosamond WD, Girman CJ, Golden SH, Schmidt MI, East HE, et al. The metabolic syndrome and 11-year risk of incident cardiovascular disease in the atherosclerosis risk in communities study. Diabetes Care. 2005;28(2):385-90. [PubMed: 15677797]

6. Sociedade Brasileira de $\mathrm{H}$, Sociedade Brasileira de $\mathrm{C}$, Sociedade Brasileira de Endocrinologia e M, Sociedade Brasileira de D, Sociedade Brasileira de Estudos da O. [I Brazilian guidelines on diagnosis and treatment of metabolic syndrome]. Arq Bras Cardiol. 2005;84 Suppl 1:1-28. [PubMed:16095065]

7. International diabetes federation tIcwadotms. Available from: http://www.idf.org/webdata/docs/IDF_Meta_def_final.pdf.

8. Salaroli LB, Barbosa GC, Mill JG, Molina MC. [Prevalence of metabolic syndrome in population-based study, Vitoria, ES-Brazil]. Arq Bras Endocrinol Metabol. 2007;51(7):1143-52. [PubMed:18157391]

9. Topic Pmbvb E, editor. New trends in classification, monitoring and management of metabolic syndrome.; The 6th FESCC Continuous Postgraduate Course in Clinical Chemistry.2006;

10. Pyorala K. Assessment of coronary heart disease risk in populations with different levels of risk. Eur Heart J. 2000;21(5):348-50. doi:10.1053/euhj.1999.1927. [PubMed:10666347]

11. Ford ES, Giles WH, Dietz WH. Prevalence of the metabolic syndrome among US adults: findings from the third National Health and Nutrition Examination Survey. JAMA. 2002;287(3):356-9. [PubMed: 11790215]

12. Bender R, Jockel KH, Richter B, Spraul M, Berger M. Body weight, blood pressure, and mortality in a cohort of obese patients. Am J Epidemiol.2002;156(3):239-45. [PubMed:12142258]

13. Grundy SM. Metabolic syndrome pandemic. Arterioscler Thromb Vasc Biol. 2008;28(4):629-36. doi: 10.1161/ATVBAHA.107.151092. [PubMed: 18174459]

14. Delavari A, Forouzanfar MH, Alikhani S, Sharifian A, Kelishadi R First nationwide study of the prevalence of the metabolic syndrome and optimal cutoff points of waist circumference in the Middle East: the national survey of risk factors for noncommunicable diseases of Iran. Diabetes Care. 2009;32(6):1092-7. doi: 10.2337/dc08-1800. [PubMed: 19279302]

15. Kelishadi R, Ardalan G, Gheiratmand R, Adeli K, Delavari A, Majdzadeh R, et al. Paediatric metabolic syndrome and associated anthropometric indices: the CASPIAN Study. Acta Paediatr. 2006;95(12):1625-34. doi: 10.1080/08035250600750072. [PubMed: 17129973]

16. Azizi F, Salehi P, Etemadi A, Zahedi-Asl S. Prevalence of metabolic syndrome in an urban population: Tehran lipid and glucose study. Diabetes Res Clin Pract. 2003;61(1):29-37. doi: 10.1016/s01688227(03)00066-4. [PubMed:12849921]

17. Derakhshan Davari R, Khoshnood A. Evaluation of abdominal obesity prevalence in diabetic patients and relationships with metabolic syndrome factors. Int J Endocrinol Metab. 2010;2010(3, Summer):143-6

18. Saki F, Karamizadeh Z. Metabolic syndrome, insulin resistance and Fatty liver in obese Iranian children. Iran Red Crescent Med J. 2014;16(5):e6656. doi:10.5812/ircmj.6656. [PubMed: 25031864]

19. Khoshdel A, Jafari SMS, Heydari ST, Abtahi F, Ardekani AA, Lak FJ The prevalence of cardiovascular disease risk factors, and metabolic syndrome among iranian military parachutists. Int Cardivas Res J. 2012;6(2):51-5.

20. Iravani SH, Sabayan B, Sedaghat S, Heydari ST, Javad P, Lankarani $\mathrm{KB}$, et al. The association of elevated serum alanine aminotransferase with metabolic syndrome in a military population in southern iran. Int Cardivas Res J. 2010;30(108):74-80.

21. Paknahad Z, Ahmadi Vasmehjani A, Maracy MR. Association of serum 25-hydroxyvitamin d levels with markers of metabolic syndrome in adult women in Ramsar, Iran. Women Health. 2014;1(1):e20124.

22. Tabatabaei-Malazy O, Fakhrzadeh H, Sharifi F, Mirarefin M, Badamchizadeh Z, Larijani B. Gender differences in association between metabolic syndrome and carotid intima media thickness. J Diabetes Metab Disord. 2012;11(1):13. doi: 10.1186/2251-6581-11-13. [PubMed: 23497686]
23. Amirkalali B, Poustchi $\mathrm{H}$, Keyvani H, Khansari MR, Ajdarkosh $\mathrm{H}$, Maadi M, et al. Prevalence of Non-Alcoholic Fatty Liver Disease and Its Predictors in North of Iran. Iran J Public Health. 2014;43(9):1275-83. [PubMed: 26175982]

24. von Elm E, Altman DG, Egger M, Pocock SJ, Gotzsche PC, Vandenbroucke JP, et al. [The Strengthening the Reporting of Observational Studies in Epidemiology [STROBE] statement: guidelines for reporting observational studies]. Gac Sanit. 2008;22(2):14450. [PubMed:18420014]

25. Goodman DS, Hulley SB, Clark LT, Davis CE, Fuster V, LaRosa JC et al. Report of the national cholesterol education program expert panel on detection, evaluation, and treatment of high blood cholesterol in adults. Arch Intern Med. 1988;148(1):36-69. [PubMed:3422148]

26. Grundy SM, Cleeman JI, Merz CN, Brewer HB, Clark LT, Hunninghake DB, et al. Implications of recent clinical trials for the National Cholesterol Education Program Adult Treatment Panel III Guidelines. J Am Coll Cardiol. 2004;44(3):720-32. doi: 10.1016/j. jacc.2004.07.001. [PubMed: 15358046]

27. Esteghamati A, Zandieh A, Zandieh B, Khalilzadeh O, Meysamie A, Nakhjavani M, et al. Leptin cut-off values for determination of metabolic syndrome: third national surveillance of risk factors of non-communicable diseases in Iran (SuRFNCD-2007). Endocrine. 2011;40(1):117-23. doi: 10.1007/s12020-011-9447-4. [PubMed: 21384232]

28. Definition WHO, editor. Diagnosis and classification of diabetes mellitus and its complications: Report of a WHO consultation.; 1999; Geneva. World Health Organization;

29. Alberti KG, Eckel RH, Grundy SM, Zimmet PZ, Cleeman JI, Donato $\mathrm{KA}$, et al. Harmonizing the metabolic syndrome: a joint interim statement of the International Diabetes Federation Task Force on Epidemiology and Prevention; National Heart, Lung, and Blood Institute; American Heart Association; World Heart Federation; International Atherosclerosis Society; and International Association for the Study of Obesity. Circulation. 2009;120(16):1640-5. doi:10.1161/CIRCULATIONAHA.109.192644. [PubMed:19805654]

30. Faam B, Hosseinpanah F, Amouzegar A, Ghanbarian A, Asghari G, Azizi F. Leisure-time physical activity and its association with metabolic risk factors in Iranian adults: Tehran Lipid and Glucose Study, 2005-2008. Prev Chronic Dis. 2013;10:E36. doi: 10.5888| pcd10.120194. [PubMed:23489641]

31. Ziaee A, Esmailzadehha N, Ghorbani A, Asefzadeh S. Association between Uric Acid and Metabolic Syndrome in Qazvin Metabolic Diseases Study (QMDS), Iran. Glob J Health Sci. 2013;5(1):155-65. doi:10.5539/gjhs.v5n1p155. [PubMed: 23283048]

32. Movahed A, Larijani B, Nabipour I, Kalantarhormozi M, Asadipooya K, Vahdat K, et al. Reduced serum osteocalcin concentrations are associated with type 2 diabetes mellitus and the metabolic syndrome components in postmenopausal women: the crosstalk between bone and energy metabolism. J Bone Miner Metab. 2012;30(6):683-91. doi: 10.1007/s00774-012-0367-z. [PubMed: 22752126]

33. Yousefzadeh G, Shokoohi M, Yeganeh M, Najafipour H. Role of gamma-glutamyl transferase (GGT) in diagnosis of impaired glucose tolerance and metabolic syndrome: a prospective cohort research from the Kerman Coronary Artery Disease Risk Study (KERCADRS). Diabetes Metab Syndr. 2012;6(4):190-4. doi: 10.1016/j. dsx.2012.08.013. [PubMed: 23199536]

34. Azimi-Nezhad M, Herbeth B, Siest G, Dade S, Ndiaye NC, Esmaily $\mathrm{H}$, et al. High prevalence of metabolic syndrome in Iran in comparison with France: what are the components that explain this? Metab Syndr Relat Disord. 2012;10(3):181-8. doi: 10.1089/ met.2011.0097. [PubMed:22283632]

35. Hadaegh F, Zabetian A, Khalili D, Safarkhani M, James WPT, Azizi F. A new approach to compare the predictive power of metabolic syndrome defined by a joint interim statement versus its components for incident cardiovascular disease in Middle East Caucasian residents in Tehran. I Epidemiol Community Health. 2012;66(5):427-32. doi: 10.1136/jech.2010.117697. [PubMed: 21051780]

36. Talaei M, Thomas GN, Marshall T, Sadeghi M, Iranipour R, Oveisgharan S, et al. Appropriate cut-off values of waist circumference 
to predict cardiovascular outcomes: 7-year follow-up in an iranian population. Int Med. 2012;51(2):139-46. doi:10.2169/internalmedicine.51.6132.

37. Zarkesh M, Faam B, Daneshpour MS, Azizi F, Hedayati M. The relationship between metabolic syndrome, cardiometabolic risk factors and inflammatory markers in a tehranian population: The tehran lipid and glucose study. Inte. Med. 2012;51(24):3329-35. doi:10.2169/internalmedicine.51.8475.

38. Ghorbani R, Naeini BA, Eskandarian R, Rashidy-Pour A, Khamseh ME, Malek M. Prevalence of metabolic syndrome according to ATPIII and IDF criteria in the Iranian population. Koomesh. 2012;14(1):Pe65-75.

39. Rezaianzadeh A, Namayandeh SM, Sadr SM. National Cholesterol Education Program Adult Treatment Panel III Versus International Diabetic Federation Definition of Metabolic Syndrome, Which One is Associated with Diabetes Mellitus and Coronary Artery Disease? Int J Prev Med. 2012;3 (8):552-8. [PubMed: 22973485]

40. Hosseinpanah F, Barzin M, Tehrani FR, Azizi F. The lack of association between polycystic ovary syndrome and metabolic syndrome: Iranian PCOS prevalence study. Clin Endocrinol (Oxf). 2011;75(5):692-7. doi: 10.1111/j.1365-2265.2011.04113.x. [PubMed: 21592169]

41. Sahebari M, Goshayeshi L, Mirfeizi Z, Rezaieyazdi Z, Hatef MR, Ghayour-Mobarhan M, et al. Investigation of the association between metabolic syndrome and disease activity in rheumatoid arthritis. ScientificWorldjournal. 2011;11:1195-205. doi: 10.1100/ tsw.2011.111. [PubMed: 21666989]

42. Esmaillzadeh A, Azadbakht L. Dietary energy density and the metabolic syndrome among Iranian women. Eur J Clin Nutr. 2011;65(5):598-605. doi:10.1038/ejcn.2010.284. [PubMed: 21224871]

43. Esteghamati A, Noshad S, Khalilzadeh O, Morteza A, Nazeri A, Meysamie A, et al. Contribution of serum leptin to metabolic syndrome in obese and nonobese subjects. Arch Med Res. 2011;42(3):244-51. doi: 10.1016/j.arcmed.2011.05.005. [PubMed: 21722822]

44. Tohidi M, Rostami M, Asgari S, Azizi F. The association between sub-clinical hypothyroidism and metabolic syndrome: A population based study. Iran J Endocrinol Metab. 2011;13(1):98-105.

45. Ghasemi A, Zahediasl S, Syedmoradi L, Azizi F. Low serum magnesium levels in elderly subjects with metabolic syndrome. Biol Trace Elem Res. 2010;136(1):18-25. doi: 10.1007/s12011-009-8522-7. [PubMed: 19763407]

46. Jalali R, Vasheghani M, Dabbaghmanesh MH, Ranjbar Omrani GH. Prevalence of metabolic syndrome among adults in a rural area. Iran JEndocrinol Metab. 2009;11(4):405-14.

47. Delavar MA, Lye MS, Khor GL, Hanachi P, Hassan ST. Prevalence of metabolic syndrome among middle aged women in Babol, Iran. Southeast Asian J Trop Med Public Health. 2009;40(3):612-28. [PubMed: 19842450]

48. Sharifi F, Mousavinasab SN, Saeini M, Dinmohammadi M. Prevalence of metabolic syndrome in an adult urban population of the west of Iran. Exp Diabetes Res. 2009;2009:136501. doi: 10.1155/2009/136501. [PubMed: 19893638]

49. Sarrafzadegan N, Kelishadi R, Baghaei A, Hussein Sadri G, Malekafzali $\mathrm{H}$, Mohammadifard N, et al. Metabolic syndrome: an emerging public health problem in Iranian women: Isfahan Healthy Heart Program. Int J Cardiol. 2008;131(1):90-6. doi: 10.1016/j.ijcard.2007.10.049. [PubMed: 18190978]

50. Hadaegh F, Ghasemi A, Padyab M, Tohidi M, Azizi F. The metabolic syndrome and incident diabetes: Assessment of alternative definitions of the metabolic syndrome in an Iranian urban population. Diabetes Res Clin Pract. 2008;80(2):328-34. doi: 10.1016/j. diabres.2008.01.003. [PubMed:18282630]

51. Zabetian A, Hadaegh F, Azizi F. Prevalence of metabolic syndrome in Iranian adult population, concordance between the IDF with the ATPII and the WHO definitions. Diabetes Res Clin Pract. 2007;77(2):251-7. doi: 10.1016/j.diabres.2006.12.001. [PubMed: 17234299]

52. Nabipour I, Amiri M, Imami SR, Jahfari SM, Shafeiae E, Nosrati A, et al. The metabolic syndrome and nonfatal ischemic heart disease; a population-based study. Int J Cardiol. 2007;118(1):48-53. doi:10.1016/j.ijcard.2006.06.017. [PubMed:16875744]

53. Sadrbafoghi SM, Salari M, Rafiee M, Namayandeh SM, Abdoli AM, Karimi M. Prevalence and criteria of metabolic syndrome in an urban population: Yazd healthy heart project. Tehran Uni Med J. 2006;64(10):90-6.

54. Fakhrzadeh H, Ebrahimpour P, Pourebrahim R, Heshmat R, Larijani B. Metabolic Syndrome and its Associated Risk Factors in Healthy Adults: APopulation-Based Study in Iran. Metab Syndr Relat Disord. 2006;4(1):28-34. doi: 10.1089/met.2006.4.28. [PubMed: 18370767]

55. Fonseca MI, Gaio R, Lopes C, Santos AC. Association between dietary patterns and metabolic syndrome in a sample of Portuguese adults. Nutr J. 2012;11:64. doi: 10.1186/1475-2891-11-64. [PubMed: 22943133]

56. Corbaton-Anchuelo A, Martinez-Larrad MT, Fernandez-Perez C, Vega-Quiroga S, Ibarra-Rueda JM, Serrano-Rios M, et al. Metabolic syndrome, adiponectin, and cardiovascular risk in Spain (the Segovia study): impact of consensus societies criteria. Metab Syndr Relat Disord. 2013;11(5):309-18. doi: 10.1089/met.2012.0115. [PubMed: 23734759]

57. Wagner A, Dallongeville J, Haas B, Ruidavets JB, Amouyel P, Ferrieres J, et al. Sedentary behaviour, physical activity and dietary patterns are independently associated with the metabolic syndrome. Diabetes Metab. 2012;38(5):428-35. doi: 10.1016/j.diabet.2012.04.005. [PubMed:22721723]

58. Beltran-Sanchez H, Harhay MO, Harhay MM, McElligott S. Prevalence and trends of metabolic syndrome in the adult U.S. population, 1999-2010. J Am Coll Cardiol. 2013;62(8):697-703. doi: 10.1016/j.jacc.2013.05.064. [PubMed: 23810877]

59. Belfki H, Ben Ali S, Aounallah-Skhiri H, Traissac P, Bougatef S, Maire B, et al. Prevalence and determinants of the metabolic syndrome among Tunisian adults: results of the Transition and Health Impact in North Africa (TAHINA) project. Public Health Nutr. 2013;16(4):582-90. doi: 10.1017/S1368980012003291. [PubMed: 22883486]

60. Wang GR, Li L, Pan YH, Tian GD, Lin WL, Li Z, et al. Prevalence of metabolic syndrome among urban community residents in China. BMC Public Health. 2013;13:599. doi: 10.1186/1471-2458-13-599. [PubMed: 23786855]

61. Pinzon JB, Serrano NC, Diaz LA, Mantilla G, Velasco HM, Martinez LX, et al. [Impact of the new definitions in the prevalence of the metabolic syndrome in an adult population at Bucaramanga, Colombia]. Biomedica. 2007;27(2):172-9. [PubMed: 17713628]

62. Florez H, Silva E, Fernandez V, Ryder E, Sulbaran T, Campos G, et al. Prevalence and risk factors associated with the metabolic syndrome and dyslipidemia in White, Black, Amerindian and Mixed Hispanics in Zulia State, Venezuela. Diabetes Res Clin Pract. 2005;69(1):63-77. doi: 10.1016/j.diabres.2004.11.018. [PubMed: 15955388]

63. Park YW, Zhu S, Palaniappan L, Heshka S, Carnethon MR, Heymsfield SB. The metabolic syndrome: prevalence and associated risk factor findings in the US population from the Third National Health and Nutrition Examination Survey, 1988-1994. Arch Intern Med. 2003;163(4):427-36. [PubMed: 12588201]

64. Barbosa PJ, Lessa I, de Almeida Filho N, Magalhaes LB, Araujo J. Criteria for central obesity in a Brazilian population: impact on metabolic syndrome. Arq Bras Cardiol. 2006;87(4):407-14. [PubMed: 17128308] 